The Promise of the Suburbs 
This page intentionally left blank 


\section{The Promise of the Suburbs}

A V I C TORIAN H ISTORY I N

L I T E R A T U R E A N D C U L T U R E

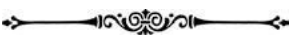

Sarah Bilston

Yale UNIVERSITY PRESS

New Haven \& London 
Copyright (C) 2019 by Sarah Bilston. All rights reserved. This book may not be reproduced, in whole or in part, including illustrations, in any form (beyond that copying permitted by Sections 107 and 108 of the U.S. Copyright Law and except by reviewers for the public press), without written permission from the publishers.

Yale University Press books may be purchased in quantity for educational, business, or promotional use. For information, please e-mail sales.press@yale.edu (U.S. office) or sales@yaleup.co.uk (U.K. office).

Set in Adobe Garamond type by IDS Infotech, Ltd. Printed in the United States of America.

Library of Congress Control Number: 2018945019

ISBN 978-0-300-I7933-0 (hardcover : alk. paper)

A catalogue record for this book is available from the British Library.

This paper meets the requirements of ANSI/NISO Z39.48-I992 (Permanence of Paper).

IO 98876543251 